\title{
Innovations in Polish family firms. Exploring employee creativity and management practices that stimulate innovative thinking
}

\section{Izabella Steinerowska-Streb ${ }^{1}$ iD, Grzegorz Głód²}

\begin{abstract}
The paper aims to recognize whether family firms that introduce the creative ideas of their employees are more innovative than the other family firms, i.e. if they introduce more products, processes, marketing, and organizational innovations. Moreover, it explores the relationship between the innovation of family businesses and their involvement in activities that stimulate innovative thinking by building a trusting workplace climate, driving employees' development, and supporting team integration. The study is based on the primary research which was conducted in Poland on a sample of 353 family firms. The statistical analysis of the research results shows that family firms that implement the creative solutions of their employees introduce significantly more product innovations than other family businesses. However, there are no differences between these two groups of family firms regarding organizational, process, and marketing innovations. Our analysis also revealed that: (i) supporting employee development is an independent factor influencing the product, process and organizational innovation of family businesses; and that (ii) building team integration by the company is an independent factor that impacts process innovation.
\end{abstract}

Keywords: family firms, innovations, creativity, product innovations, process innovations, organizational innovations, marketing innovations, Poland

\section{INTRODUCTION}

Innovations are the main source of competitiveness (Madrid-Guijarro, Garcia, \& Van Auken, 2009) and performance (Park, Misra, Reddy, \& Jaber, 2019) of

\footnotetext{
1 Izabella Steinerowska-Streb, dr hab., prof. UE University of Economics in Katowice, ul. 1-go Maja 50, 40-287 Katowice. Poland, e-mail: streb@ue.katowice.pl (ORCID ID: 0000-0001-5379-5730).

2 Grzegorz Głód, dr hab., prof. UE, University of Economics in Katowice, ul. 1-go Maja 50, 40-287 Katowice Poland, e-mail: gglod@ue.katowice.pl (ORCID ID: 0000-0001-9699-2427).
} 
contemporary firms. They are also recognized as a key factor in the long-term success of companies (Kammerlander, Dessì, Bird, Floris, \& Murru, 2015). Consequently, many businesses pursue strategies focused on achieving competitive advantage to implement innovations (Park et al., 2019). The ability to create and implement innovations becomes one of the major challenges for family firms (Covin \& Wales, 2012; Filser, Brem, Gast, Kraus, \& Calabrò, 2016). It is because they are "endowed with a bundle of beliefs and practices that constitute their tradition" (Erdogan, Rondi, \& De Massis, 2019, p. 1) and they often prefer to retain historical success formulas rather than respond to changes that have occurred in the market (Classen, Carree, Van Gils, \& Peters, 2014; Kellermanns, Eddleston, Sarathy, \& Murphy, 2012; Lattuch, 2019). The spectrum of factors determining the innovation of family businesses is broad. Due to the influence of family ownership on organizational goals, risk-taking propensity and long-term investment horizons, family firm innovation processes and outcomes are likely to differ from those evidenced in non-family firms (De Massis, Wang, \& Chua, 2018; Kotlar \& Chrisman, 2018; Li \& Daspit, 2016; Lorenzo \& Núñez-Cacho, 2013; Urbinati, Franzò, De Massis, \& Frattini, 2017). However, some determinants of family firms' innovation are common for both family and non-family businesses. One of these is employee creativity, which is perceived as a fundamental condition of innovation (Hon \& Lui, 2016; Slatten, 2014; Tang, Yu, Cooke, \& Chen, 2017). An increasing number of studies have found that employee creativity contributes to organizational innovation, effectiveness, survival and longterm success (Anderson, Potocnik, \& Zhou, 2014; Coelho, Augusto, \& Lages, 2011; Hon \& Lui, 2016; Hong, Hou, Zhu, \& Marinova, 2018). Evidence suggests that the creativity of employees assists organizations in becoming more efficient and more responsive to new development opportunities (Siddiqi \& Qureshi, 2016). It also supports their adaption to changes within the business environment (Beheshtifar \& Zare, 2013). Considering the positive influence of creativity on innovations, a number of firms attempt to stimulate creative thinking among their employees (Doran \& Ryan, 2017).

Although previous studies explored the relationship between employee creativity and innovation (Anderson et al., 2014; Hon \& Lui, 2016; Khalili, 2018), very few researchers considered these factors specifically in relation to family firms. In Poland, this issue has so far been discussed only occasionally. A review of the literature shows that there is no evidence indicating whether family businesses, in which employees generate new ideas, introduce more innovations than other family firms. Furthermore, there is a lack of evidence exploring whether family businesses stimulate employees' creative thinking to enhance the company's innovation by building a trusting workplace climate, driving employees' development, and supporting team integration. Likewise, it is not clear if family firms that try to establish 
a creative environment are more innovative than other family businesses. This study aims to address these gaps. As such, it explores whether family firms that introduce the creative ideas of their employees are more innovative than other family firms, i.e. if they introduce more product, process, marketing, and organizational innovations. Moreover, the study identifies the relationship between the innovation of family businesses and involvement in activities that stimulate innovative thinking by building a trusting workplace climate, driving employees' development, and supporting team integration. To reach the research aims the results of the primary research were analyzed. The study addresses two key research questions:

RQ1: Are there differences between the innovation level of family firms that introduce the creative ideas of their employees and the rest of family businesses?

RQ2: Considering the job contextual factors associated with building a trusting workplace climate, driving employees' development and supporting team integration, what are the differences between the innovation of family firms that stimulate and do not stimulate employees' creative thinking?

Answers to the presented research questions help to provide three main contributions to the family firm literature. First, the paper develops knowledge about the management of employee creativity and innovation in Polish family firms. Second, our study extends knowledge about the factors affecting the innovation of Polish family firms. Finally, it contributes to the innovation literature exploring the diffusion of innovations within family firms.

The paper comprises of six major parts. The next section discusses the literature on the subject justifying the selection of the underlying hypotheses. This is followed by the section outlining the methodology of the presented study. Next, the findings of the primary research and their analysis are presented. The following section of the paper contains conclusions drawn on the basis of the conducted research. Finally, the last section provides a brief summary of the study and suggestions for research areas to be explored in the future.

\section{LITERATURE REVIEW}

\section{Family firms' innovations and employees' creative ideas}

Family firms have many features that distinguish them from non-family firms (Astrachan, 2010). These features include family ownership, governance, management, and intergenerational succession (Beck, Janssens, Kommelen, 
\& Sluismans, 2009). A unique feature of family firms is the socioemotional engagement of the family in running the business (Bratnicka-Myśliwiec, Pośpiech-Wronka, \& Ingram, 2019; Gòmez-Meja, Kynes, Numez-Nickel, \& Moyano-Tuentes, 2007; Sharama \& Sharama, 2011; Zientara, 2017). Due to this form of engagement, the family shapes the organizational culture of the business and the way it sets its goals (Martin and Gomez-Mejia, 2016; Sharama \& Sharama, 2011; Sułkowski \& Marjański, 2009). Accordingly, the family decides about the levels and forms of business innovativeness (Lattuch, 2019).

A review of the literature on family firms reveals that many family firms are reluctant to introduce any changes to their products, choosing instead to preserve the heritage created by their forefathers (Kellermanns et al., 2012; Lattuch, 2019; Lim, Lubatkin, \& Wiseman, 2010). By not deviating from the path set by the firm's founders, a lot of family firms choose less risky (Boers, Ljungkvist, Brunninge, \& Nordqvist, 2017) and less innovative solutions (König, Kammerlander, \& Enders, 2013). Consequently, they are more risk-averse than non-family firms (Hiebl, 2014) and prefer to introduce exploitative innovations. Such innovations are in line with the families' socioemotional concerns because they are less uncertain in nature than explorative innovations (Bammens, Notelaers, \& Van Gils, 2014). However, it is important to recognize that family businesses are not a homogeneous group. There are also such family firms that are able and willing to take more risk. They implement innovations aimed at their long-term orientation (Gentry, Dibrell, \& Kim, 2016) and consider these innovations as a fundamental activity that is required to deal with an unstable environment. Such family businesses are aware that to survive through generations, they are required to innovate (Hoy, 2006). Thus, although new product development is frequently expensive, and, most importantly, "often entails high levels of market and technological risk" (De Massis, Frattini, \& Lichtenthaler, 2012) these family firms try to adjust their products to the changes taking place in the environment that "exerts a strong influence on family businesses innovation" (Kotlar, De Massis, Fang, \& Frattini, 2014). Hence, some family businesses are innovative. The innovative strategies of such family firms can even be aggressive (Kellermanns et al., 2012).

The heterogeneity of family businesses appears not only in their different tendencies to innovate but also concerns their various approaches to absorbing employee creativity. Namely, some family firms do not consider employees' ideas as a potential source of innovation, even when they come forward with creative solutions regarding firms' products, processes, organization or firms' marketing activities. In such companies, creative employees are often not recognized as a solution to potential business problems. Mostly, it is because they are afraid of losing control over the trajectory of traditional family products. Conversely, other family firms create 
innovation cultures supporting individual and team creativity to generate new ideas. For such creative companies, the insights of their employees are of crucial importance. These firms are aware that due to creative employees, firms may solve many specific challenges (Slatten, 2014) and gain competitive advantage (Granot, 2016; Hassan, Malik, Hasnain, Faiz \& Abbas, 2013). Such family businesses may perceive creativity and innovation as a source of their long-term sustainability. Likewise, employee creativity can be recognized by these companies as "one of the prerequisites of firm innovation" (Bammens et al., 2014, p. 862). Such innovative family companies can promote innovative cultures by supporting the creativity of their employees and embracing their new ideas. Thus, the companies may develop processes that drive employee creativity at individual, team, and organizational levels.

Considering that creativity is the first step of innovation (Bammens et al., 2014; Slatten, 2014), and a key driver of innovative changes in organizations (Moghimi \& Subramaniam, 2013), we assume that there is a relationship between employee creativity and family firms' innovation. As there are four different types of innovation identified in the Oslo Manual (2005) - product, process, organizational, and marketing innovations - we postulate that:

H1. Employee creativity positively influences the introduction of different types of innovations in family firms.

\section{Innovation of family businesses and stimulating employee creativity by building a climate of trust in the workplace}

Although employee creativity is fundamental for firm innovation (Bammens et al., 2014, p. 862), in isolation, it is insufficient to support innovation (Slatten, 2014). Accordingly, "creativity and innovativeness require a certain level of internal force that pushes the individual to persevere in the face of challenges in creative work" (Parjanen, 2012, s. 109). Therefore, researchers have been trying to identify what is the basis of employee engagement in the creative process and innovation and they attempt to find out why people get involved in creative activity. Likewise, they try to determine the initial state of inducing creativity (Hassan et al., 2013; Tierney \& Farmer, 2004; Unsworth, 2001; Zhou $\&$ George, 2003). So far, it has been widely recognized that employee creativity is driven by individual cognitive styles and personal attributes (Cekmecelioglu \& Gúnsel, 2013). These attributes include creative ability, skills, and motivation (Granot, 2016). However, recent empirical evidence indicates that in addition to the personal characteristic affecting the creativity of employees (Hassan et al., 2013), work-related contextual factors also play a significant role in the creativity of employees and company innovation (Table 1 ). 
Table 1. A review of job-specific contextual factors that have been mainly explored in the literature in relation to employee creativity and innovation

\begin{tabular}{|c|c|c|c|}
\hline Author & $\begin{array}{l}\text { Year of the } \\
\text { publication }\end{array}$ & $\begin{array}{l}\text { Job-specific contextual } \\
\text { factor }\end{array}$ & $\begin{array}{l}\text { Impact on innovation and } \\
\text { employee creativity }\end{array}$ \\
\hline $\begin{array}{l}\text { Hassan, Malik, Hasnain, } \\
\text { Faiz \& Abbas }\end{array}$ & 2013 & $\begin{array}{l}\text { job complexity } \\
\text { relationship with supervisor }\end{array}$ & $\begin{array}{l}\text { positive effect on firm's } \\
\text { innovation }\end{array}$ \\
\hline $\begin{array}{l}\text { Rodrigues \& Marques } \\
\text { Veloso }\end{array}$ & 2013 & trust & $\begin{array}{l}\text { increases creativity of } \\
\text { employees and firm innovation }\end{array}$ \\
\hline Cekmecelioglu \& Gűnsel & 2013 & $\begin{array}{l}\text { creative organizational } \\
\text { climate }\end{array}$ & $\begin{array}{l}\text { positive effect on firm's } \\
\text { innovation }\end{array}$ \\
\hline Hon \& Lui & 2015 & $\begin{array}{l}\text { individual- and group-level } \\
\text { uncertainness }\end{array}$ & hinders creativity and innovation \\
\hline Ghosh & 2015 & $\begin{array}{l}\text { creative climate } \\
\text { self-leadership } \\
\text { workplace innovative } \\
\text { orientation }\end{array}$ & $\begin{array}{l}\text { all variables enhance employee } \\
\text { creativity }\end{array}$ \\
\hline Tung \& Yu & 2016 & leadership & enhances creativity \\
\hline $\begin{array}{l}\text { Giustiniano, Lombardi, } \\
\text { \& Cavaliere }\end{array}$ & 2016 & $\begin{array}{l}\text { individuals' orientation } \\
\text { toward learning from others }\end{array}$ & $\begin{array}{l}\text { significantly enhances } \\
\text { organizational creativity }\end{array}$ \\
\hline Doran \& Ryan & 2017 & $\begin{array}{l}\text { job-specific training } \\
\text { creative thinking stimuli } \\
\text { knowledge generation } \\
\text { stimuli }\end{array}$ & $\begin{array}{l}\text { positively relates to innovation } \\
\text { output }\end{array}$ \\
\hline Khalili & 2018 & $\begin{array}{l}\text { leader-member exchange } \\
(\mathrm{LMX})\end{array}$ & $\begin{array}{l}\text { There is a positive and } \\
\text { significant relationships } \\
\text { between LMX and employees' } \\
\text { creativity and innovation }\end{array}$ \\
\hline $\begin{array}{l}\text { Imran, Ilyas, Aslam, \& } \\
\text { Fatima }\end{array}$ & 2018 & $\begin{array}{l}\text { knowledge processes } \\
\text { knowledge-intensive culture }\end{array}$ & $\begin{array}{l}\text { knowledge processes have } \\
\text { a positive impact on firm } \\
\text { performance and employee } \\
\text { creativity; a knowledge- } \\
\text { intensive culture has } \\
\text { a strengthening effect on the } \\
\text { relationship between knowledge } \\
\text { processes and employee } \\
\text { creativity }\end{array}$ \\
\hline Zaitouni \& Ouakouak & 2018 & $\begin{array}{l}\text { leadership support } \\
\text { coworker support }\end{array}$ & $\begin{array}{l}\text { leadership support and } \\
\text { coworker support exert positive } \\
\text { influences on employee } \\
\text { creativity }\end{array}$ \\
\hline Xu \& Wang & 2019 & $\begin{array}{l}\text { leader creativity } \\
\text { expectations }\end{array}$ & $\begin{array}{l}\text { leader creativity expectations } \\
\text { insignificantly and positively } \\
\text { are related to employee radical } \\
\text { creativity }\end{array}$ \\
\hline Tien, Chang, \& Kuo & 2019 & $\begin{array}{l}\text { self-directed learning } \\
\text { self-monitoring }\end{array}$ & $\begin{array}{l}\text { Self-directed learning has an } \\
\text { influence on the creativity of } \\
\text { individuals with accumulated } \\
\text { work experience; low self- } \\
\text { monitoring influences the } \\
\text { creativity of people with less } \\
\text { work experience }\end{array}$ \\
\hline
\end{tabular}


The organizational climate that promotes trust in the company is one of the job contextual factors positively influencing the creativity of employees and innovation (Isaken, 2017). The findings of Rodrigues and Marques Veloso (2013) show that an organizational climate built on trust increases creativity and cooperation between co-workers, and leads to innovation in companies. Similarly, the study of Ceserani (2014, p. 302) reveals that "high trust releases energy, abilities, imagination, and achievements." Low trust does the opposite. According to Ceserani $(2014$, p. 303) trust is the foundation of successful innovation in that "in a low-trust organization, people's energy is focused on defending themselves. In a high-trust organization, people's energy is released to be used on creativity, innovation, and performance".

The organizational climate that induces trust is strongly influenced by the leaders (Dul \& Ceylan, 2014; Lau \& Liden, 2008; Vinarski-Peretz, \& Carmeli, 2011). According to Isaken (2017), by sharing information candidly and regularly with employees, leaders may strengthen levels of organizational trust, safety, justice, and openness. Moreover, leaders can affect trust in the company by directly solving difficult problems instead of avoiding them. Similarly, Parjanen (2012) and Zhang \& Zhou (2014) state that leaders can support the creativity of employees by appreciating the contribution of individual employees and showing confidence in the working group (Parjanen, 2012; Zhang \& Zhou, 2014).

To facilitate innovation and creativity, the leaders of family firms may build a friendly, fear-free psychological environment, and promote organizational behavior that avoids both individual- and group-level uncertainties that hinder creativity (Hon, Bloom, \& Crant, 2014; Hon \& Lui, 2016). They may also support psychological safety and intergroup relationships (Dackert, 2016). All these activities should build and strengthen trust in the organization. Considering that these activities may lead family firms to greater employee creativity and consequently, to greater innovation, we postulate that:

\section{H2. All types of innovation in family businesses are determined by building a climate of trust in the workplace.}

\section{Innovation of family businesses and stimulating employee creativity by promoting team integration}

The spectrum of job-specific contextual factors related to employee creativity and innovation is wide. Team integration has been recognized as another determinant of creativity and innovation in organizations. The team's integration mainly refers to the cooperation of individual team members and their shared understanding. This also applies to the involvement of 
team members in achieving common goals and their willingness to exchange information. According to Nawi, Lee, Kamar, and Hamid (2012), the members of an effective integrated team feel a "sense of ownership" (p. 50), clearly understanding their roles and responsibilities.

Although team integration is difficult to build, family firms may influence it. To enhance innovation and employees' creativity, family businesses may support social integration within the group of employees and develop intergroup relationships (Dackert, 2016). Their leaders can impact the team's integration by encouraging team cohesion, enhancing social relations, and providing tasks that require cross-functional teamwork (Isaken, 2017). Leaders are also able to support team work and enhance team outcomes by organizing team integration meetings that support both task and team work (Salas, Diazgranados, Klein, Burke, Stagl, Goodwin, \& Halpin, 2008). Thus, we postulate that:

H3. All types of innovation in family businesses are determined by promoting team integration.

\section{Innovation of family businesses and stimulating employee creativity by supporting employee development}

The Oslo Manual (2018) stresses that "innovation is based on a learning process" (Organisation for Economic Co-operation and Development [OECD], 2018 , p. 45). It identifies different knowledge-based activities that firms can undertake in pursuing innovation. These include employee training activities. Such training is required not only to develop innovation but, in particular, it is needed to stimulate employee creativity.

Sarri, Bakouros, and Petridou (2010) state that to increase employee creativity and innovativeness, it is crucial to identify the training needs of individuals and then design training adjusted to these needs. Similarly, the study of Ghosh (2015) reveals that exposing the employee to training, mentoring, and on-the-job coaching can bring out the creative performance of an employee. These findings are in line with the recent theories of team innovation, highlighting that external knowledge acquisition develops team members in searching for novel routines and practices (Jiang \& Chen, 2016).

Doran \& Ryan (2017) provide an explanation of the existence of the relationship between the development of employees' knowledge and creativity. They argue that job training boosts employees' knowledge about job context, which in turn increases their potential to generate new ideas. Bearing this in mind, we suggest that supporting the development of 
employees in family firms, influences the innovation of family firms, and we postulate that:

H4. All types of innovation in family businesses are determined by supporting the development of employees.

\section{RESEARCH METHODS}

This paper is based on the results of a primary quantitative research and is a part of a larger study dedicated to explore economic and social issues of family businesses in Poland. In this study, the ownership and management criteria were chosen to identify our population of Polish family firms. Accordingly, the term "family firm" has been applied to a business having one person or a family as the whole or majority owner, and where the owner/ family are also the managers (Kraśnicka, 2017).

For the purpose of the study, we adopted a definition of innovation used by O'Sullivan and Dooley (2009), according to which innovation refers to making changes (large and small, radical and incremental) to the products, processes, and services that result in the introduction of something new for the organization that adds value to customers and contributes to the organization's knowledge store. Using the Oslo Manual (2005) classification, we considered product, process, organizational, and marketing innovations. A product innovation is understood as "the introduction of a good or service that is new or significantly improved with respect to its characteristics or intended uses. This includes significant improvements in technical specifications, components and materials, incorporated software, user-friendliness, or other functional characteristics" (OECD, 2005, p. 48). A business process innovation has come to be used to refer to "the implementation of a new or significantly improved production or delivery method. This includes significant changes in techniques, equipment and/or software" (OECD, 2005, p. 49). The term "marketing innovations" has been applied to "the implementation of a new marketing method involving significant changes in product design or packaging, product placement, product promotion or pricing" (OECD, 2005, p. 49). Finally, organizational innovation is defined as "the implementation of a new organizational method in the firm's business practices, workplace organization or external relations" (OECD, 2005, p. 52). In this study, product, process, organizational, and marketing innovations were used as dependent variables.

A questionnaire was used as the method of our primary data collection. It was based on the recommendations of the Oslo Manual (2005) and research on innovation. As recommended (Oslo Manual, 2005), the questionnaire adapted 
short sentences and a number of binary scale responses (yes or no). A series of questions relating to the research objectives were developed through a thorough review of existing research on innovation, employee creativity, team development and integration, trust, and other issues relevant to our project.

We chose an e-mail questionnaire to collect data as it allowed respondents to participate in the study at a convenient time - an important factor considering the busy life and work commitments of our target group. Free and flexible access to the questionnaire ensured that respondents could take their time to read and fully understand the questions and complete the questionnaire thoroughly. Finally, our data collection method was supported by research findings showing that an email survey often stimulates a higher response level than regular studies (Saunders, Lewis, \& Thornhill, 2009; Seale 2004).

The questionnaire was directed to owner-managers of family firms. All respondents were asked to provide information about innovations in their company. Based on it, we identified family firms that introduced product, process, marketing, and organizational innovations. The indications of our respondents led us also to the identification of family businesses with creative employees (employee creativity was the first of four independent variables that were examined). We considered employee creativity "as the creation of a valuable and useful product, service, idea, procedure or process by individuals working in a complex social system" (Hon \& Lui, 2016, p. 863). A firm was classified as a firm with creative employees when the managers who responded to the questionnaire declared that employees come up with new and innovative ideas. That question was adopted from Cekmecelioglu and Günsel (2013).

Considering the provided responses, we also identified family businesses that care about developing a trusting workplace climate (trusting workplace climate was the second independent variable that was examined). Following the definition of trusting climate of Shih, Chiang, and Chen (2012, p. 1059), a workplace climate is "rooted in three related components: (i) the belief that one's colleagues are capable and skilled, (ii) the desire to do good for others and believe that one's own interests will not be harmed by colleagues, and (iii) the belief that the other party is motivated by the principle of fairness." Considering that leaders may build a trusting workplace climate by sharing information candidly and regularly with employees, and by promoting organizational behavior that avoids both individual- and group-level uncertainties (Hon et al., 2014; Hon \& Lui, 2016), we asked our respondents whether these two activities are undertaken in their companies. This led us to the recognition of family firms that build a trusting workplace climate.

The third independent variable that was studied was supporting team integration. We defined supporting team integration as organizations' 
engagement in inter-firm interactions (Franz, Leicht, Molenaar, \& Messner 2017). To measure the activities that family firms perform to support team integration, we asked whether managers (i) provide tasks that require crossfunctional teamwork, and simultaneously (ii) organize team integration meetings that support both task and team work (Salas et al., 2008). The companies engaging in these two activities have been classified as companies supporting team integration.

Finally, our fourth independent variable was driving employees' development. Considering the research results of Jiang and Chen (2016) to measure the family firms' activities that drive employees' development, we asked owner-managers whether (i) the company organizes job training that boosts employees' knowledge about job context, and (i) supports different employee training activities.

A research sample was generated from the database of the Polish Family Firm Initiative (Inicjatywa Firm Rodzinnych IFR). Initially, a pilot survey was conducted on a sample of 15 family businesses. Considering the feedback from users, a modified, final version of the questionnaire was sent to our sample.

The quality of all returned questionnaires was verified in terms of completeness and correctness. Some questionnaires were removed from the database due to discrepancies or incomplete data. Finally, 353 fully completed questionnaires were used for statistical analysis. The surveyed sample consisted of micro, small, medium, and large family businesses. The respondents represented all industries including trade, services, production and construction. There were also enterprises with mixed activities. Table 2 shows the descriptive statistics regarding the sample.

Table 2. Descriptive statistics regarding the sample

\begin{tabular}{llrr}
\hline & Specification & $\mathbf{N}$ & \% \\
\hline \multirow{3}{*}{ Firms size } & micro firms & 183 & 51.7 \\
& small firms & 100 & 28.2 \\
& medium firms & 40 & 11.3 \\
& large firms & 31 & 8.8 \\
Industry & & & \\
& construction & 19 & 5.4 \\
& trade & 65 & 18.4 \\
& mixed & 101 & 28.5 \\
& production & 27 & 7.6 \\
& services & 142 & 40.1 \\
\hline
\end{tabular}


Statistical analysis of the data was carried out in a few stages. Firstly, using the $X^{2}$ test, significant differences $(p<0.05)$ for selected variables were calculated. Secondly, the correspondence analysis was used to identify the relation of analyzed variables to different types of innovations. Finally, the independent predictors of innovations were calculated based on the logistic regression equation. These calculations enabled the recognition of the chances for the implementation of different types of innovations by family firms.

\section{RESULTS}

The empirical evidence indicates that family businesses, including (i) those whose employees generate creative ideas and (ii) those whose employees do not come up with new solutions, implement all types of innovations. However, greater innovative activity is evidenced among family firms whose employees develop some creative ideas concerning firm products, processes, organization, or marketing (Figure 1). Among the family firms whose employees generated and did not generate creative ideas, no statistical differences were found, neither in the case of organizational innovations $\left(X^{2}=0.53 ; p=0.4677\right)$ nor in marketing $\left(X^{2}=2.19 ; p=0.1389\right)$ and process $\left(X^{2}=3.24 ; p=0.0718\right)$ innovations. Employee creativity turned out to significantly determine only the implementation of product innovations $\left(X^{2}=11.83 ; p=0.006\right)$ of family businesses.

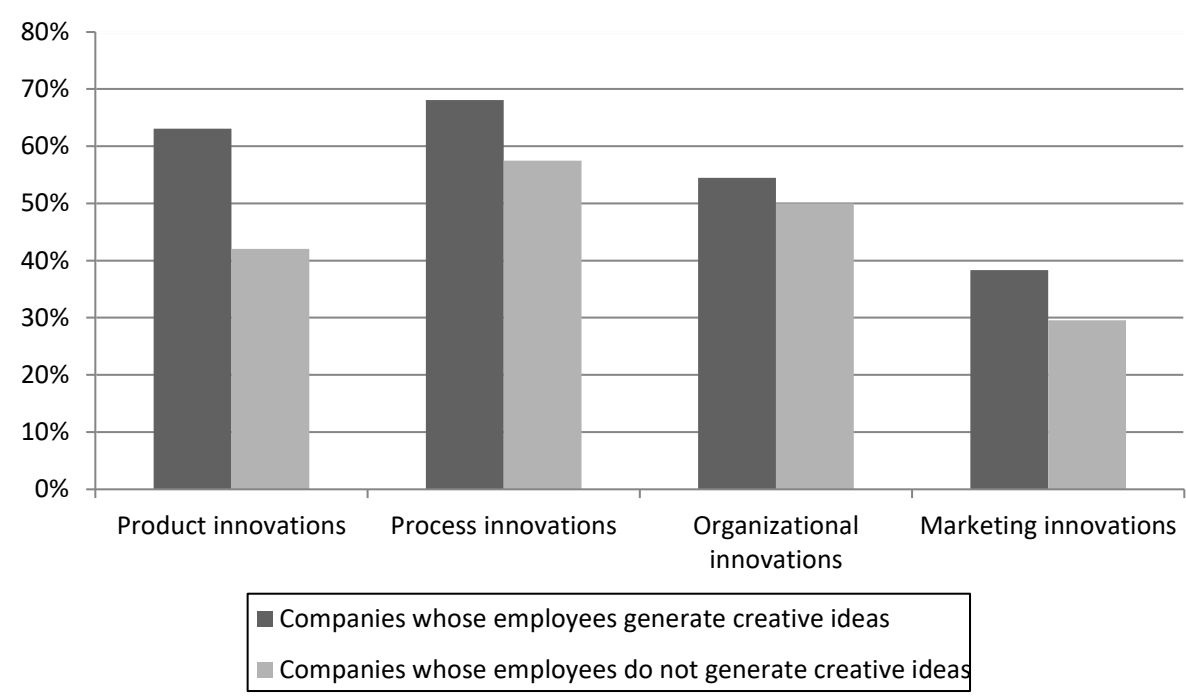

Figure 1. The implementation of products, processes, organizational and marketing innnovations in family firms whose employees do and do not generate new ideas 

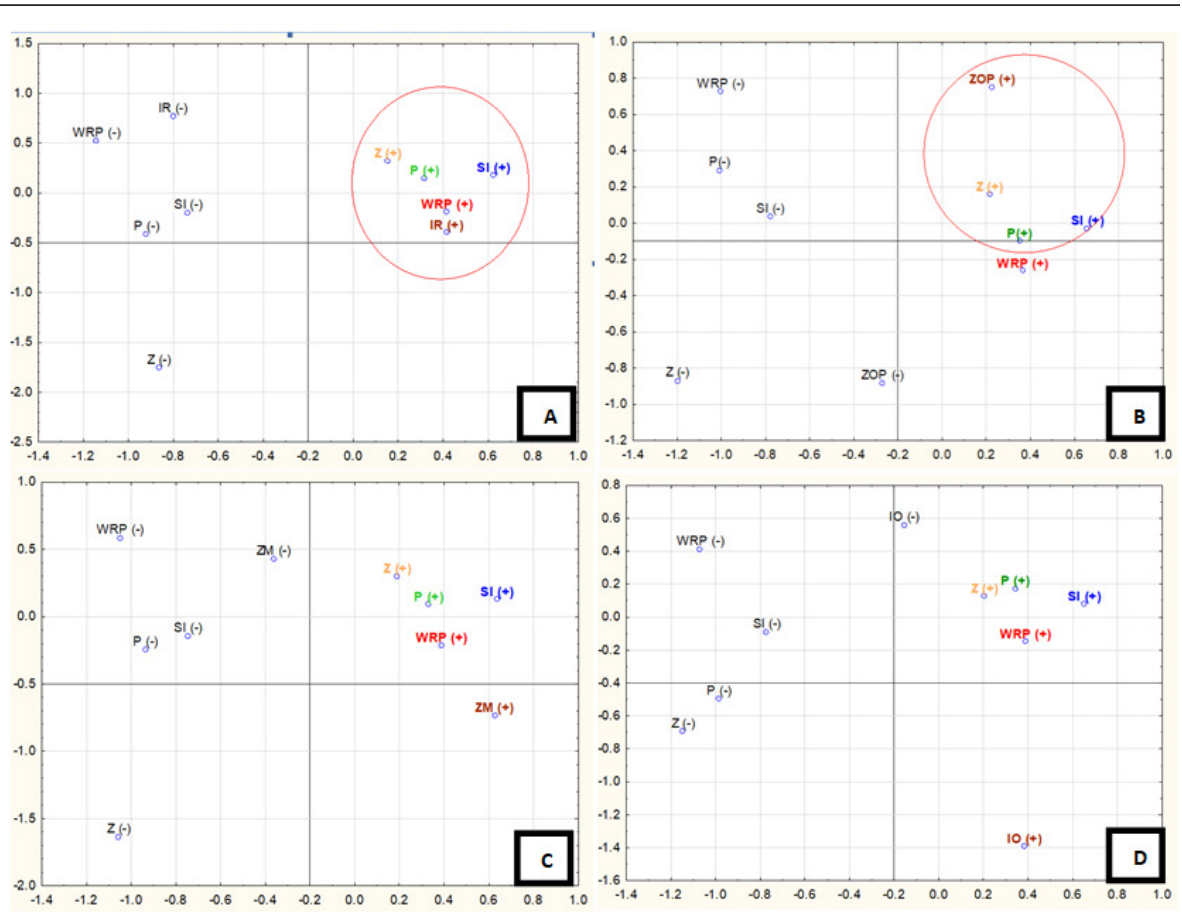

$\mathrm{P}(+)$ - family businesses whose employees provide creative ideas concerning the firm

$\mathrm{P}(-)$ - family businesses whose employees do not provide creative ideas concerning the firm

IR (+) - companies that introduce process innovations

IR (-) - companies that do not introduce process innovations

IP $(+)$ - companies that introduce product innovations

IP (-) - companies that do not introduce product innovations

ZM $(+)$ - companies that introduce marketing innovations

$\mathrm{ZM}(-)$ - companies that do not introduce marketing innovations

ZOP $(+)$ - companies that introduce organizational innovations

ZOP (-) - companies that do not introduce organizational innovations

SI $(+)$ - companies that support team integration in the organization

SI (-) - companies that do not support team integration in the organization

$\mathrm{Z}(+)$ - companies that target an organizational culture of trust within an organization

$Z(-)$ - companies that do not target an organizational culture of trust within an organization

WRP $(+)$ - companies that support employees' development

WRP (-) - companies that do not support employees' development

Figure 2. The correspondence analysis of investigated variables and the implementation of process $(A)$, organizational $(B)$, marketing $(C)$ and product (D) innovations by family firms

The correspondence analysis found out that the family firms whose employees generate creative ideas are characterized by the introduction of products and processes innovations. Contrary, the remaining family firms were 
unlikely to introduce product and process innovations. The implementation of marketing innovations was not associated with (i) those family businesses whose employees generate creative ideas; nor with (ii) those family firms whose employees do not create new solutions (Figure 2).

Almost $85 \%$ of respondents declared that their firms build a trusting workplace climate (Figure 3 ). Interestingly, between this group of family firms and the group of family businesses that do not care about a trusting climate in their organization, there were no statistical differences concerning the implementation of any type of innovation - product $\left(X^{2}=1.4 ; p=0.2359\right)$; process $\left(X^{2}=0.04 ; \mathrm{p}=0.8331\right)$; organizational $\left(X^{2}=2.69 ; \mathrm{p}=0.01011\right)$ and marketing $\left(X^{2}=1.52 ; p=0.2183\right)$.

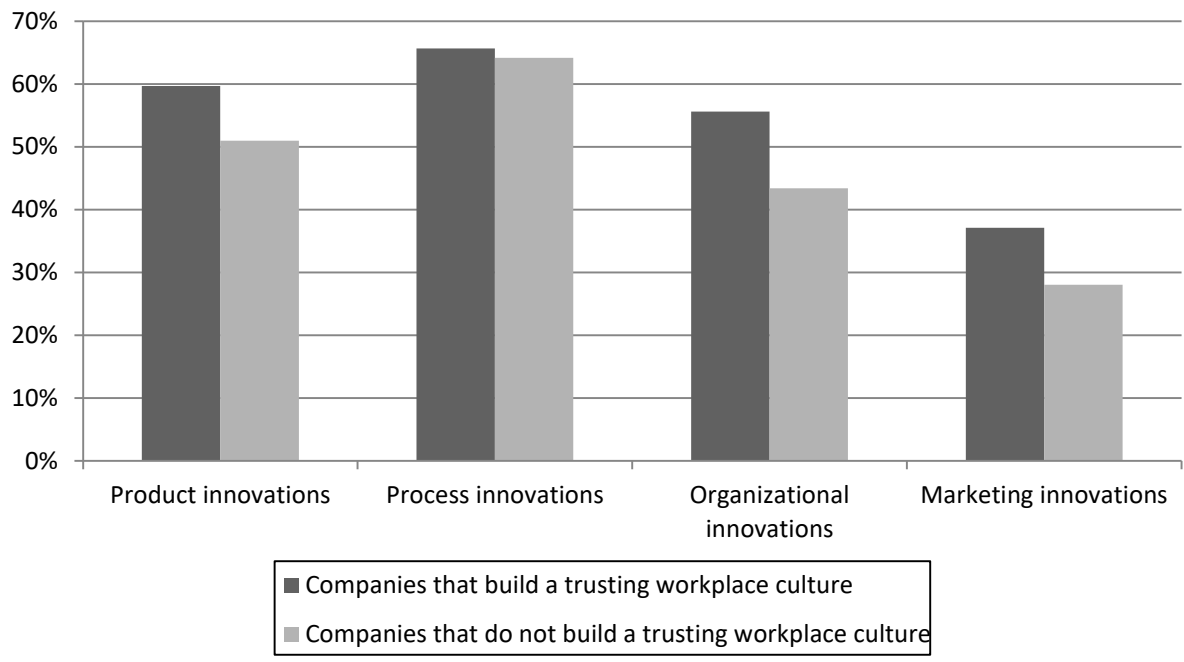

Figure 3. The implementation of product, process, organizational and marketing innovations in family firms that build and do not build a trusting workplace culture

The majority of family firms included in the study support the development of their employees. $28 \%$ of the respondents indicated that they neither organize nor finance any training of their personnel. The activity of these family businesses was similar to the rest of the companies only in the implementation of organizational innovations. Other types of innovation (product, process, and marketing innovations) were less frequent (Figure 4). Among those family firms that support and do not support employees' development, no statistical differences were found only in the case of organizational innovations $\left(X^{2}=0.17 ; p=0.6762\right)$. However, supporting the 
development of employees significantly determined the implementation of product $\left(X^{2}=8.36 ; p=0.0038\right)$, process $\left(X^{2}=33.75 ; p<0.001\right)$, and marketing $\left(X^{2}=13.9 ; p=0.0003\right)$ innovations.

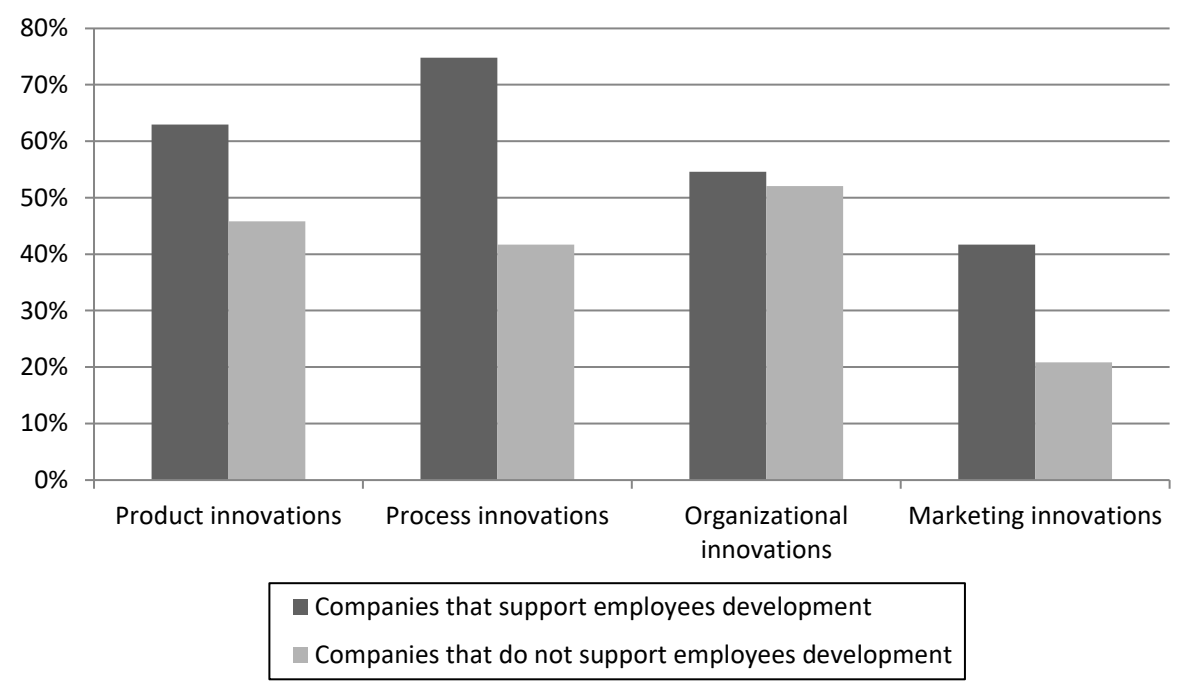

Figure 4. The implementation of product, process, organizational and marketing innovations in family firms that support and do not support employees' development

$54 \%$ of family firms reported that they support team integration in the organization. The comparison of these family businesses to the rest of respondents shows that this group was characterized by greater innovation implementation (Figure 5). However, the statistical differences between these two groups of family businesses appeared only in the case of process innovation ( $\left.X^{2}=13.9 ; p=0.0003\right)$.

The correspondence analysis revealed that the family firms that build a trusting workplace climate, support team integration, and drive employees' development are characterized by the implementation of processes and organizational innovations. This analysis also showed that these activities of family businesses do not correspond to organizational and marketing innovations (Figure 2). 


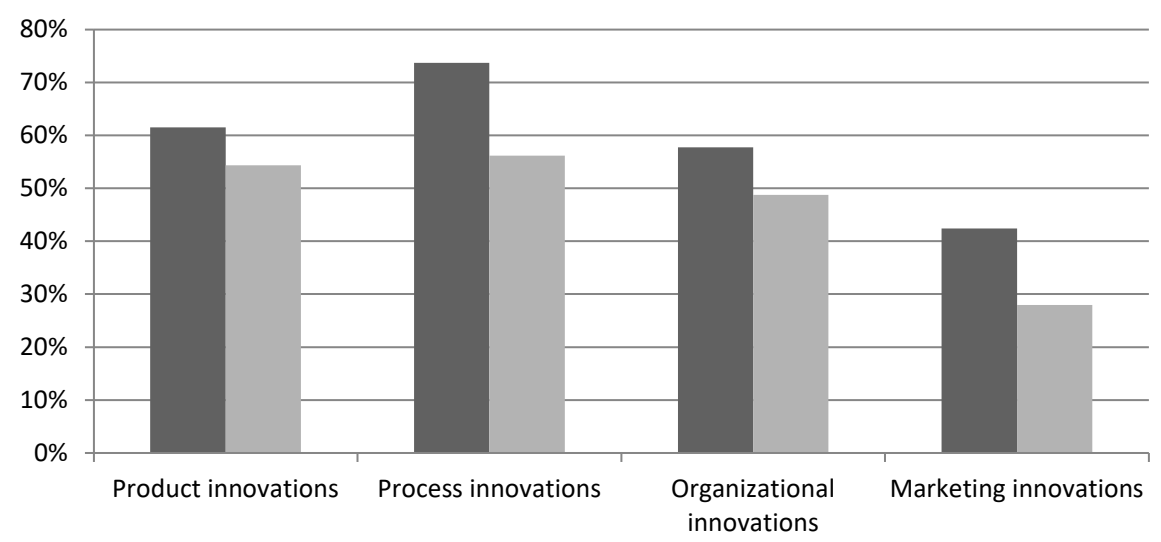

\begin{tabular}{|l|}
\hline Companies that support team integration \\
Companies that do not support team integration \\
\hline
\end{tabular}

Figure 5. The implementation of product, process, organizational and marketing innovations in family firms that support and do not support team integration

To find the independent predictors of all investigated variables on innovation of family businesses, a regression analysis was performed. The results of it are presented in Table 3 . In summary, the regression analysis highlighted that:

- employee creativity is an independent factor influencing product innovations;

- supporting the development of employees is an independent factor that impacts product, process and marketing innovations;

- building team integration is an independent factor that influences process innovations.

The regression analysis additionally showed that:

- the chances of the implementation of product innovation by family firms increase when the company supports employees development (1.67 times); or when the firm has employees that generate creative ideas (more than 2 times);

- the chances of the introduction of process innovation in family businesses raise when the firm supports employees' development (3.5 times); or when it builds team integration (more than 1.8 times);

- the chances of the implementation of marketing innovation by family companies increase more than 2 times when the firm supports employees' development. 
Table 3. Regression analysis for chosen variables

\begin{tabular}{|c|c|c|c|c|}
\hline & $\begin{array}{l}\text { Companies } \\
\text { that support } \\
\text { employee } \\
\text { development }\end{array}$ & $\begin{array}{l}\text { Companies } \\
\text { that have } \\
\text { creative } \\
\text { employees }\end{array}$ & $\begin{array}{l}\text { Companies } \\
\text { that build } \\
\text { a trusting } \\
\text { workplace } \\
\text { culture }\end{array}$ & $\begin{array}{l}\text { Companies } \\
\text { that support } \\
\text { team } \\
\text { integration }\end{array}$ \\
\hline \multicolumn{5}{|c|}{ Product innovation } \\
\hline Estimation & 0.516 & 0.771 & 0.231 & 0.055 \\
\hline Standard error & 0.262 & 0.261 & 0.319 & 0.240 \\
\hline$t(335)$ & 1.971 & 2.949 & 0.729 & 0.261 \\
\hline $\mathrm{p}$ & 0.045 & 0.003 & 0.467 & 0.818 \\
\hline$-95 \% C L$ & $<0.001$ & 0.257 & -0.393 & -0.417 \\
\hline$+95 \% \mathrm{CL}$ & 1.031 & 1.285 & 0.854 & 0.538 \\
\hline Chi-kwadrat & 3.883 & 8.698 & 0.531 & 0.0532 \\
\hline$p$ & 0.048 & 0.003 & 0.466 & 0.816 \\
\hline Odds ratio & 1.675 & 2.161 & 1.260 & 1.057 \\
\hline$-95 \% C L$ & 1.001 & 1.293 & 0.675 & 0.659 \\
\hline$+95 \% \mathrm{CL}$ & 2.804 & 3.614 & 2.350 & 1.695 \\
\hline \multicolumn{5}{|c|}{ Process innovation } \\
\hline Estimation & 1.257 & 0.152 & -0.298 & 0.595 \\
\hline Standard error & 0.268 & 0.281 & 0.346 & 0.255 \\
\hline$t(335)$ & 4.684 & 0.543 & -0.861 & 2.331 \\
\hline $\mathrm{p}$ & 4.096 & 0.588 & 0.389 & 0.020 \\
\hline$-95 \% C L$ & 0.729 & -0.399 & -0.978 & 0.093 \\
\hline$+95 \% \mathrm{CL}$ & 1.785 & 0.704 & 0.382 & 1.096 \\
\hline Chi-kwadrat & 21.942 & 0.294 & 0.741 & 5.433 \\
\hline $\mathrm{p}$ & 2.822 & 0.587 & 0.389 & 0.0198 \\
\hline Odds ratio & 3.515 & 1.164 & 0.742 & 1.812 \\
\hline$-95 \% C L$ & 2.073 & 0.671 & 0.376 & 1.097 \\
\hline$+95 \% \mathrm{CL}$ & 5.959 & 2.022 & 1.466 & 2.994 \\
\hline \multicolumn{5}{|c|}{ Organizational innovation } \\
\hline Estimation & -0.124 & 0.143 & 0.378 & 0.309 \\
\hline Standard error & 0.2593 & 0.258 & 0.311 & 0.233 \\
\hline$t(335)$ & -0.478 & 0.552 & 1.215 & 1.311 \\
\hline $\mathrm{p}$ & 0.633 & 0.581 & 0.225 & 0.190 \\
\hline$-95 \% C L$ & -0.634 & -0.365 & -0.233 & -0.153 \\
\hline$+95 \% \mathrm{CL}$ & 0.386 & 0.650 & 0.9895 & 0.765 \\
\hline Chi-kwadrat & 0.228 & 0.305 & 1.476 & 1.716 \\
\hline
\end{tabular}




\begin{tabular}{|c|c|c|c|c|}
\hline & $\begin{array}{l}\text { Companies } \\
\text { that support } \\
\text { employee } \\
\text { development }\end{array}$ & $\begin{array}{l}\text { Companies } \\
\text { that have } \\
\text { creative } \\
\text { employees }\end{array}$ & $\begin{array}{l}\text { Companies } \\
\text { that build } \\
\text { a trusting } \\
\text { workplace } \\
\text { culture }\end{array}$ & $\begin{array}{l}\text { Companies } \\
\text { that support } \\
\text { team } \\
\text { integration }\end{array}$ \\
\hline $\mathrm{p}$ & 0.633 & 0.580 & 0.224 & 0.190 \\
\hline Odds ratio & 0.883 & 1.153 & 1.459 & 1.357 \\
\hline$-95 \% C L$ & 0.530 & 0.694 & 0.791 & 0.828 \\
\hline$+95 \% \mathrm{CL}$ & 1.471 & 1.916 & 2.690 & 2.148 \\
\hline \multicolumn{5}{|c|}{ Marketing innovation } \\
\hline Estimation & 0.796 & 0.189 & 0.226 & 0.399 \\
\hline Standard error & 0.294 & 0.281 & 0.344 & 0.246 \\
\hline$t(335)$ & 2.705 & 0.675 & 0.659 & 1.618 \\
\hline $\mathrm{p}$ & 0.007 & 0.499 & 0.512 & 0.106 \\
\hline$-95 \% C L$ & 0.217 & -0.362 & -0.451 & -0.085 \\
\hline$+95 \% \mathrm{CL}$ & 1.375 & 0.742 & 0.902 & 0.883 \\
\hline Chi-kwadrat & 7.318 & 0.4556 & 0.430 & 2.619 \\
\hline$P$ & 0.007 & 0.199 & 0.156 & 0.106 \\
\hline Odds ratio & 2.217 & 1.209 & 1.253 & 1.489 \\
\hline$-95 \% C L$ & 1.212 & 0.696 & 0.637 & 0.918 \\
\hline$+95 \% \mathrm{CL}$ & 3.956 & 2.100 & 2.464 & 2.419 \\
\hline
\end{tabular}

Note: significant parameters with p-values lower than 0.05 are highlighted.

\section{DISCUSSION}

This study identified a relationship between the creativity of employees and the innovation of family businesses. The presented evidence shows that family firms, whose employees generate creative ideas, introduce significantly more product innovations than other family businesses. Interestingly, this relationship is related only to this specific form of innovation. In the case of organizational, process and marketing innovations, no differences between these two groups of family firms were found. Thus, the study reveals that the positive impact of employee creativity on the introduction of innovations by family firms does not always exist. It applies only to one type of innovation: product innovation. Consequently, the hypothesis $\mathrm{H} 1$, according to which employees' creativity positively influences the introduction of all types of innovations in family firms, can be confirmed only partially.

The relationship between employee creativity and product innovation suggests that product development solutions generated by employees are 
particularly useful for family businesses. This may be due to the fact that employees of family firms know both the needs of the customers and the concerns of the family regarding the possibility of losing control over the trajectory of traditional family products. As the ideas generated by employees may be rooted in the tradition of a family firm, they can be particularly valuable from the point of view of family business owners.

By showing that in family firms, employee creativity positively influences the introduction of product innovations, our findings are in line with previous studies (Hassan et al., 2013). Likewise, our results provide additional evidence to support the research showing links between creativity and innovation (Anderson et al., 2014; Hon \& Lui, 2016; Slatten, 2014).

The second dimension of the study related to family firms' management practices aimed at fostering employees' creativity to increase the company's innovativeness. We considered three forms of these practices including: building a trusting workplace climate, supporting employees' development, and promoting team integration. It was assumed that all types of innovation in family businesses are determined by the above variables $(\mathrm{H} 2 ; \mathrm{H} 3 ; \mathrm{H} 4)$. However, none of these hypotheses $(\mathrm{H} 2 ; \mathrm{H} 3 ; \mathrm{H} 4)$ could be fully confirmed. Our analysis revealed only that: (i) supporting employee development is an independent factor influencing the product, process and organizational but not the marketing innovation of family businesses; and that (ii) building team integration by the company is an independent factor that impacts process innovation.

Unexpectedly, the creation of a trusting workplace climate was not identified as an independent variable determining the implementation of any type of innovation by family firms. The lack of a relationship between building a trusting workplace climate and innovation in family businesses may appear due to family firms being generally based on trust (Lattuch, 2019). They offer their employees job security, which typically is greater in family businesses than in non-family firms (Bassanini, Breda, Caroli, \& Rebérioux, 2013). Accordingly, it may be that a trusting workplace climate is so naturally deeply rooted in the psychological environment of family businesses that it creates a friendly enough atmosphere to foster creativity and innovation. Therefore, any activities undertaken by leaders to create a climate of trust in the workplace may not lead to creating additional value in this field.

An important achievement that emerges from this study is that the support of employee development is an independent factor influencing the product, processes, and organizational innovation of family businesses. This finding supports the conclusions of the study of Sarri et al. (2010), who argue that to increase employee creativity and innovativeness, it is crucial to identify the training needs of individuals. Thus, as human resources "are 
critical for long-term strategic gain" in family firms (Clinton, 2016, p. 176), and innovation is essential for their long-term competitive advantage (Gentry et al., 2016), it is extremely important for family businesses to support employee development. As the findings of this study show, due to such activities, family firms can increase their innovation. Memili and Welsh (2012) state that family businesses should especially take care of the workers outside of the family. According to them, employees that do not belong to the family can play a key role in the development of family businesses because such employees may present other than family views on the strategy of the firm.

Showing the relationship between employee development and the product, processes and organizational innovation of family businesses, this study demonstrates how crucial knowledge assets are for the family firm's innovativeness. Importantly, such results are in line with previous research conducted by Palacios, Gil, and Garrigos (2009), which reveals that knowledge resources have a positive impact on the firm's innovative performance. They also support the recent theories of team innovation that emphasize team processes centered on collective knowledge activities, such as knowledge acquisition. These theories have also highlighted that external knowledge acquisition develops team members in searching for novel routines and practices (Jiang \& Chen, 2016).

A meaningful finding of our study is also the conclusion concerning team integration activities and the implementation of process innovation. Our results indicate that there is a relationship between these variables. Thus, the paper supports the previous studies in the field, suggesting that enhancing innovation and creativity among enterprises requires social integration within the group of employees (Dackert, 2016). Importantly, our study shows that the relationship between the social integration of the team and the firms' innovation also applies to family businesses. Thus, similarly to the studies of Clinton (2016) and Steinerowska-Streb (2016), our study findings emphasize the role of human resources in the innovation of family firms and show that care for employees in family businesses contributes to their strategies.

The results of this study, concerning the relationships between firm innovation and supporting employee development as well as building team integration, are in line with the empirical evidence indicating that not only the personal characteristics of employees affect the creativity of employees (Hassan et al., 2013; Khalili, 2018; Rodrigues \& Marques Veloso, 2013). As evidenced, job contextual factors also play a significant role in the creativity of employees and company innovativeness.

Finally, it is essential to note that this study does not identify a trusting workplace climate as an independent factor that influences family firm innovation. Thus, it can be concluded that although family businesses offer 
their employees greater job security than non-family firms (Bassanini et al., 2013), they must also stimulate employee creativity in different ways to encourage them to generate new innovative ideas.

\section{CONCLUSION, IMPLICATIONS, AND DIRECTIONS FOR FUTURE RESEARCH}

It is generally accepted that contemporaryemployees constitute a fundamental source of creativity and innovation in organizations (Bammens et al., 2014). Thus, many firms are trying to build an organizational climate that supports employees' creativity, including management support, strategy, working environment, customer orientation, or leadership (Doran \& Ryan, 2017; Tuan, Giang, \& Nguyen, 2014). However, it is not a rule that the creative thinking of employees, or actions undertaken within an organization to enhance employee creativity, will shift the firm to a greater level of innovation (Drozdowski, Zakrzewska, Puchalska, Morchat, \& Mroczkowska, 2010). The basis for this can be found in two main reasons. Firstly, employee creativity may not always lead to innovation because only some of the ideas provided by the employees are valuable to a firm. Thus, not all of the ideas generated by employees are introduced into business practice. Secondly, only some companies appreciate that creative employees may solve many different challenges (Slatten, 2014) and increase their long-term competitive advantage (Granot, 2016; Hassan et al., 2013). Hence, in companies that are not interested in the creativity of employees, employees generating innovative ideas do not contribute to the emergence of innovation. Nevertheless, the capabilities of organizations are often determined by intrepreneurs that are able to critically look at products, services and / or work practices in the organization. These intrepreneurs can generate ideas that may be used to create new, innovative services/products and methods of work (Dovey, 2009).

The present study reveals that family firms that are aware of the importance of creative employees and that introduce the creative ideas of their staff members into business practice are more innovative than the rest of family businesses. This study also shows that many family businesses undertake a variety of activities to develop an environment supporting employee creativity and firm innovation. Despite this, some of them succeed in their attempts to introduce greater innovation. Instead, we found that the company's innovation growth exists when the firm supports employee development.

The findings of this study contribute to both the family firm and innovation literature. They extend the knowledge about the factors affecting 
the introduction of different types of innovation by family firms. The paper also exerts the knowledge about managing employees in Polish family firms.

In addition to developing knowledge in the field, the study also provides some practical implications for family businesses. Based on the findings, we suggest that family firms should promote the creativity of their employees. As evidence, there is a relationship between the employees' creativity and product innovation of family businesses. Thus, it shows that workers can be crucial actors in reshaping and improving business practices and the business performance of family firms. These findings can help to inform ownermanagers of family businesses on how to manage individuals and teams for the benefit of both - their firms and employees.

Finally, the study has some policy implications, and it indicates that policies should promote and encourage companies that support the development of knowledge of their employees. The latter can lead family firms to be more innovative and, consequently, contribute to the acceleration of economic growth and development.

Drawing on this study, we call for additional research investigating employee creativity and innovation in family firms. Future studies could focus on other human resource management practices that aim to create a creative workforce. Moreover, future research may be conducted in different socioeconomic environments and on a larger sample of businesses to verify and add to the findings presented in this paper. Finally, future studies can use both qualitative and quantitative methodologies to measure employee creativity in order to complement and expand research results. In-depth qualitative interviews can help to answer the "why" and "what" questions revealing reasons for employee involvement in creating new, innovative ideas.

This study has several limitations. First, we analyzed the impact of three selected activities that stimulate employees' innovative thinking on family firm innovation. Undoubtedly, different determinants and environmental factors may also play a role. Second, our research was conducted only in Poland. Thus, further research in other countries can add to the findings of the present study.

\section{References}

Anderson, N., Potocnik, K., \& Zhou, J. (2014). Innovation and creativity in organizations: A state-of-the-science review, prospective commentary, and guiding framework. Journal of Management, 40(5), 1297-1333. http://doi.org/10.1177/0149206314527128

Astrachan, J.H. (2010). Strategy in family business: Toward a multidimensional research agenda. Journal of Family Business Strategy, 1(1), 6-14. http:// dx.doi.org/10.1016/j.jfbs.2010.02.001 
Bammens, Y., Notelaers, G., \& Van Gils, A. (2014). Implications of family business employment for employees' innovative work involvement. Family Business Review, 28(2), 123-144. http://doi. org/10.1177/0894486513520615

Bassanini, A., Breda, T., Caroli, E., \& Rebérioux, A. (2013). Working in family firms: Paid less but more secure? Evidence from French matched employer-employee data. ILR Review, 66(2), 433-466. http://doi. org/10.1177/001979391306600206

Beheshtifar, M., \& Zare, E. (2013). Employee creativity: A compulsory factor in organizations. Interdisciplinary Journal of Contemporary Research, 5(2), 242-247. http://doi.org/10.1177/0258042X16676664

Beck, L., Janssens, W., Kommelen, T., \& Sluismans, R. (2009). Research on innovation capacity antecedents, distinguishing between family and nonfamily businesses. Paper presented at the EIASM Workshop on Family Firms Management Research, June 7-9, Hasselt, Belgium. Retrieved from http://www.researchgate.net/publication/228781684_Research_ on_innovation_capacity_antecedents_distinguishing_between_family_ and_non-family_businesses

Bratnicka-Myśliwiec, K., Wronka- Pośpiech, M., \& Ingram T. (2019). Does socioemotional wealth matter for competitive advantage? A case of Polish family businesses. Journal of Entrepreneurship, Management and Innovation, 15(1), 123-146. http://doi.org/10.7341/20191515

Boers, B., Ljungkvist, T., Brunninge, O., \& Nordqvist, M. (2017). Going private: A socioemotional wealth perspective on why family controlled companies decide to leave the stock-exchange. Journal of Family Business Strategy, 8(2), 74-86. http://doi.org/10.1016/j.jfbs.2017.01.005

Cekmecelioglu, H.G., \& Gúnsel, A. (2013). The effects of individual creativity and organizational climate on firm innovativeness. Procedia - Social and Behavioral Sciences, 99(2013), 257-264. http://doi.org/10.1016/j. sbspro.2013.10.493

Ceserani, J. (2014). Innovation and trust - the path to mastery. Industrial and Commercial Training, 46(6), 302-306. http://doi.org/10.1108/ICT-042014-0024

Classen, N., Carree, M., Van Gils, A., \& Peters, B. (2014). Innovation in family and non-family SMEs: An exploratory analysis. Small Business Economics, 42(3), 595-609. http://doi.org/10.1007/s11187-013-9490-z

Clinton, E. (2016). Human resources in the family business - maximising the power of your people. The Irish Journal of Management, 35(2), 176-178. http://doi.org/10.1515/ijm-2016-0014

Coelho, F., Augusto, M., \& Lages, L.F. (2011). Contextual factors and the creativity of frontline employees: The mediating effects of role stress and intrinsic motivation. Journal of Retailing, 87(1), 31-41. http://doi. org/10.1016/j.jretai.2010.11.004 
Covin, J.G., \& Wales, W.J. (2012). The measurement of entrepreneurial orientation. Entrepreneurship Theory and Practice, 36(4), 677-702. http://doi.org/10.1111/j.1540-6520.2010.00432.x

Dackert, I. (2016). Creativity in teams: The impact of team members' affective well-being and diversity. Open Journal of Social Sciences, 4, 19-28. http:// doi.org/10.4236/jss.2016.49003

De Massis, A., Wang, H., \& Chua J.H. (2018). Counterpoint: How heterogeneity among family firms influences organizational change. Journal of Change Management, 19(1), 37-44. http://doi.org/10.1080/14697017.2017.1419808

De Massis, A., Frattini, F., \& Lichtenthaler, U. (2012). Research on technological innovation in family firms: Present debates and future directions. Family Business ReviewXX(X), 1-22.http://doi.org/10.1177/0894486512466258

Doran, J., \& Ryan, G. (2017). The role of stimulating employees' creativity and idea generation in encouraging innovation behaviour in Irish firms. Irish Journal of Management, 36(1), 32-48. http://doi.org/10.1515/ijm-2017-0005

Dovey, K. (2009). The role of trust in innovation. The Learning Organization, 16(4), 311-325. http://doi.org/10.1108/09696470910960400

Drozdowski, R., Zakrzewska, A., Puchalska, K., Morchat, M., \& Mroczkowska, D. (2010). Wspieranie Postaw Proinnowacyjnych przez Wzmacnianie Kreatywności Jednostki. Warsaw: Polska Agencja Rozwoju Przedsiębiorczości. Retrieved from https://www.parp.gov.pl/storage/ publications/pdf/9721ogktouk4ue.pdf

Dul, J., \& Ceylan, C. (2014). The impact of a creativity-supporting work environment on a firm's product innovation performance. Journal of Product Innovation Management, 31, 1254-1267. http://doi. org/10.1111/jpim.12149

Erdogan, I., Rondi, E., \& De Massis, A. (2019). Managing the tradition and innovation paradox in family firms: A family imprinting perspective. Entrepreneurship Theory and Practice, 44(1), 1-35. http://doi. org/10.1177/1042258719839712

Filser, M., Brem, A., Gast, J., Kraus, S., \& Calabrò, A. (2016). Innovation in family firms - examining the inventory and mapping the path. International Journal of Innovation Management, 20(06), 1-39. http:// doi.org/10.1142/S1363919616500547

Franz, B., Leicht, R., Molenaar, K., \& Messner, J. (2017). Impact of team integration and group cohesion on project delivery performance. Journal of Construction Engineering and Management, 143(1), 1-12. http://doi. org/10.1061/(ASCE)CO.1943-7862.0001219

Gentry, R., Dibrell, C., \& Kim, J. (2016). Long-term orientation in publicly traded family businesses, Evidence of a dominant logic. Entrepreneurship Theory and Practice, 40(4), 733-757. http://doi.org/10.1111/etap.12140 Ghosh, K. (2015). Developing organizational creativity and innovation. Toward a model of self-leadership, employee creativity, creativity climate and workplace innovative orientation. Management Research Review, 38(11), 1126-1148. http://doi.org/10.1108/MRR-01-2014-0017 
Giustiniano, L., Lombardi, S., \& Cavaliere, V. (2016). How knowledge collecting fosters organizational creativity, Management Decision, 54(6), 14641496. http://doi.org/10.1108/MD-04-2015-0111

Gòmez-Meja, L. R., Kynes, K. T., Numez-Nickel, M., \& Moyano-Tuentes. H. (2007). Socioemotional health and business risk in family-controlled firms: Evidence from Spanish olive oil mills. Administrative Science Quarterly, 52, 106-137. http://doi.org/stable/i20109899

Granot, E. (2011). Creative managers and managing creativity: A hermeneutic exploration. American Journal of Business, 26(2), 161-182. http://doi. org/10.1108/19355181111174534

Hassan, M.U., Malik, A.A. Hasnain, A., Faiz, M.F., \& Abbas, J. (2013). Measuring employee creativity and its impact on organization innovation capability and performance in the banking sector of Pakistan. World Applied Sciences Journal, 24(7), 949-959. http://doi.org/10.5829/idosi. wasj.2013.24.07.13253

Hiebl, M.R.W. (2014). Risk aversion in the family business: The dark side of caution. Journal of Business Strategy, 35(5), 38-42. http://doi. org/10.1108/JBS-09-2013-0087

Hon, A.H.Y., Bloom, M., \& Crant, M. (2014). Overcoming resistance to change and enhancing creative performance. Journal of Management, 40(3), 919-941. http://doi.org/10.1177/0149206311415418

Hon, A.H.Y., \& Lui, S.S. (2016). Employee creativity and innovation in organizations. Review, integration, and future directions for hospitality research.InternationalJournalofContemporary Hospitality Management, 28(5), 862-885. http://doi.org/10.1108/IJCHM-09-2014-0454

Hong, J., Hou, B., Zhu, K., \& Marinova, D. (2018). Exploratory innovation, exploitative innovation and employee creativity: The moderation of collectivism in Chinese context. Chinese Management Studies, 12(2), 268-286. http://doi.org/10.1108/CMS-11-2016-0228

Hoy, F. (2006). The complicating factor of life cycles in corporate venturing. Entrepreneurship Theory Practice, 30(6), 831-836. http://dx.doi. org/10.1111/j.1540-6520.2006.00154.x

Isaken, S. (2017). Leadership's role in creative climate creation. In M.D. Mumford \& S. Helmin (Eds.), Handbook of Research on Leadership and Creativity. Northampton, Massachusetts: Edward Elgar Publishing.

Imran, M. Ilyas, M., Aslam, U., \& Fatima, T. (2018). Knowledge processes and firm performance, the mediating effect of employee creativity. Journal of Organizational Change Management, 31(3), 512-531. http://doi. org/10.1108/JOCM-10-2016-0202

Jiang, Y., \& Chen, C.C. (2016). Integrating knowledge activities for team innovation.Effects oftransformationalleadership.JournalofManagement, 44(5), 1819-1847. http://doi.org/10.1177/0149206316628641

Khalili, A. (2018). Creativity and innovation through LMX and personal initiative. Journal of Organizational Change Management, 31(2), 323333. http://doi.org/10.1108/JOCM-09-2016-0183 
Kammerlander, N., Dessì, C., Bird, M., Floris, M., \& Murru, A. (2015). The impact of shared stories on family firm innovation: A multicase study. Family Business Review, 28(4), 332 -354. http://doi. org/10.1177/0894486515607777

Kellermanns, F.W., Eddleston, K.A., Sarathy, R., \& Murphy, F. (2012). Innovativeness in family firms: A family influence perspective. Small Business Economics, 38(1), 85-101. http://doi.org/10.1007/s11187-010-9268-5

Kotlar, J., \& Chrisman, J.J. (2018). How family involvement influences organizational change. Journal of Change Management, 19(1), 26-36. http://doi.org/10.1007/s11187-010-9268-5

Kotlar, J., De Massis, A., Fang, H., \& Frattini, F. (2014). Strategic reference points in family firms. Small Business Economics, 43(3), 597-619. http:// doi.org/10.1007/s11187-014-9556-6

König, A., Kammerlander, N., \& Enders, A. (2013). The family innovator's dilemma. How family influence affects the adoption of discontinuous technologies by incumbent firms. Academy of Management Review, 38(3), 418-441. http://doi.org/10.5465/amr.2011.0162

Kraśnicka, T. (2017), Sukcesja i kondycja ekonomiczno-finansowa firm rodzinnych w Polsce i Czechach. Wyniki badań jakościowych. Zeszyty Naukowe Poiltechniki Ślqaskiej, 108, 203-214.

Lattuch, F. (2019). Family firm innovation strategy, contradictions and tradition. Journal of Business Strategy, 40(3), 36-42. http://doi.org/10.1108/JBS03-2018-0046

Lau, D.C., \& Liden, R.C. (2008). Antecedents of coworker trust: Leaders' blessings. Journal of Applied Psychology, 93, 1130-1138. http://doi. org/10.1037/0021-9010.93.5.1130

Li, Z., \& Daspit, J.J. (2016). Understanding family firm innovation heterogeneity: A typology of family governance and socioemotional wealth intentions. Journal of Family Business Management, 6(2), 103-121. http://doi. org/10.1108/JFBM-02-2015-0010

Lim, E.N.K., Lubatkin, M.H., \& Wiseman, R.M. (2010). A family firm variant of the behavioral agency theory. Strategic Entrepreneurship Journal, 4(3), 197-211. http://doi.org/10.1002/sej.91

Lorenzo, D., \& Núñez-Cacho, P. (2013). Do family firms have specific barriers to innovation? A first approach. Paper presented at the IFERA 2013 Conference, University of St. Gallen, St. Gallen. Retrieved from http:// www2.uca.es/serv/catedra-empresa-familiar/docs/DO\%20FAMILY\%20 FIRMS\%20HAVE\%20-Lorenzo_y_Nunez-Cacho_Ifera_2013.pdf

Madrid-Guijarro, A., Garcia, D., \& Van Auken, H. (2009). Barriers to innovation among Spanish manufacturing SMEs. Journal of Small Business and Management, 47(4), 465-488. http://doi.org/10.1111/j.1540627X.2009.00279.x

Martin, G., \& Gomez-Mejia, L. (2016). The relationship between socioemotional and financial wealth: Re-visiting family firm decision making. Management Research. Journal of the Iberoamerican 
Academy of Management, 14(3), 215-233. http://doi.org/10.1108/ MRJIAM-02-2016-0638

Memili, E., \& Welsh, H.B. (2012). Towards a theory of nonfamily employees' organizational identification and attachment in family firms. Journal of Technology Management, 7(3), 255-269. http://doi. org $/ 10.1108 / 17468771311325167$

Moghimi, S., \& Subramaniam, I.D. (2013). Employees' creative behavior: The role of organizational climate in Malaysian SMEs. International Journal of Business and Management, 8(5), 1-12. http://doi.org/10.5539/ijbm.v8n5p1

Nawi, M.N.M., Lee, A., Kamar, K.A.M., \& Hamid, Z.A. (2012). Critical success factors for improving team integration in industrialised building system (IBS) construction projects: the Malaysian case. Malaysian Construction Research Journal, 10(1), 45-63.

OECD. (2005). Oslo Manual, Guidelines for Collecting and Interpreting Innovation Data (3 ${ }^{\text {rd }}$ ed.). Paris, France: Organization for Economic Cooperation and Development.

OECD/Eurostat. (2018). Oslo Manual: Guidelines for Collecting, Reporting and Using Data on Innovation ( $4^{\text {th }}$ ed.). Luxemburg: OECD Publishing.

O'Sullivan, D., \& Dooley, L. (2009). Applying Innovation. Thousand Oakes, CA: Sage Publications.

Palacios, D., Gil, I., \& Garrigos, F. (2009). The impact of knowledge management practices on innovation and entrepreneurship in the biotechnology and telecommunications industries. Small Business Economics, 32, 291-301. jstor.org/stable/40344552

Parjanen, S. (2012). Experiencing creativity in the organization: From individual creativity to collective creativity. Interdisciplinary Journal of Information, Knowledge, and Management, 7, 110-128. http://doi. org/10.28945/1580

Park, H.Y., Misra, K., Reddy, S., \& Jaber, K. (2019). Family firms' innovation drivers and performance: A dynamic capabilities approach. Journal of Family Business Management, 9(1), 4-23. http://doi.org/10.1108/JFBM11-2017-0039

Rodrigues, A.F.C., \& Marques Veloso, A.L.O. (2013). Organizational trust, risk and creativity. Review of Business Management 14(49), 545-561. http:// doi.org/10.7819/rbgn.v15i49.1334

Salas, E., Diazgranados, D., Klein, C., Burke, C.S., Stagl, K.C., Goodwin, G.F., \& Halpin, S. M. (2008). Does team training improve team performance? A meta-analysis. Human Factors: The Journal of the Human Factors and Ergonomics Society, 50(6), 903-933. http://doi. org/10.1518/001872008X375009

Sarri, K.K., Bakouros, I.L., \& Petridou, E. (2010). Entrepreneur training for creativity and innovation. Journal of European Industrial Training, 34(3), 270-288. http://doi.org/10.1108/03090591011031755

Saunders, M., Lewis, P., \& Thornhill, A. (2009). Research Methods for Business Students ( $3^{\text {rd }}$ ed.). London, UK: Financial Times/Prentice Hall. 
Seale, C. (2004). Researching Society and Culture. London, UK, Sage.

Shih, H.-A., Chiang, Y.-H., \& Chen, T.-J. (2012). Transformational leadership, trusting climate, and knowledge-exchange behaviors in Taiwan. The International Journal of Human Resource Management 23(6), $1057-$ 1073. http://doi.org/10.1080/09585192.2011.639546

Slatten, T. (2014). Determinants and effects of employee's creative self-efficacy on innovative activities. International Journal of Quality and Service Sciences, 6(4), 326-347. http://doi.org/10.1108/IJQSS-03-2013-0013

Sharama, P., \& Sharama, S. (2011). Drivers of proactive Environmental strategy in family firms. Business Ethics Quarterly, 21(2), 309-334. http:// doi.org/10.5840/beq201121218

Siddiqi, H., \& Qureshi, M. (2016). The impact of employees' creativity on the performance of the firm. Research Issues in Social Sciences, 1, 1-12.

Steinerowska-Streb, I. 2016, Wybrane determinanty zatrudniania pracowników w polskich przedsiębiorstwach rodzinnych. Ekonomika i Organizacja Przedsiębiorstwa, 3(794), 68-78.

Sułkowski, Ł., \& Marjański, A. (2009). Firmy Rodzinne. Jak Osiqggnq̨ć Sukces w Sztafecie. Warszawa: Poltext.

Tang, G., Yu, B., Cooke, F.L., \& Chen, Y. (2017). High-performance work system and employee creativity. The roles of perceived organisational support and devolved management, Personnel Review, 46(7), 1318-1334. http:// doi.org/10.1108/PR-09-2016-0235

Tien, H.K., Chang, B.L., \& Kuo, Y.K. (2019). Does experience stimulate or stifle creativity?. European Journal of Innovation Management, 22(3),422445. http://doi.org/10.1108/EJIM-02-2018-0042

Tuan, N.P, Giang, P.H., \& Nguyen, D.N. (2014). The impact of organizational culture on innovation activities the case of $X$ corporation in Vietnam. Journal of Global Management Research. Retrieved from http:// gmrjournal.uqam.ca/documents/GMRJ-V10N1-JUN2014-29-36.pdf

Tung, F.C., \& Yu, T.W. (2016). Does innovation leadership enhance creativity in high-tech industries? Leadership \& Organization Development Journal, 37(5), 579-592. http://doi.org/10.1108/LODJ-09-2014-0170

Tierney, P., \& Farmer, S.M. (2004). The Pygmalion process and employee creativity. Journal of Management, 30(3), 413-32. http://doi. org/10.1016/j.jm.2002.12.001

Xu, F., \& Wang, X. (2019). Leader creativity expectations and follower radical creativity: Based on the perspective of creative process. Chinese Management Studies, 13(1), 214-234. http://doi.org/10.1108/CMS-04-2018-0489

Urbinati, A., Franzò, S., De Massis, A., \& Frattini, F. (2017). Innovation in family firms: A review of prior studies and a framework for future research. In A. Brem \& E. Viardot (Eds), Revolution of Innovation Management. (pp. 213-246). London: Palgrave Macmillan.

Unsworth, K. (2001). Unpacking creativity. Academy of Management Review, 26, 289-297. http:doi.org/10.5465/amr.2001.4378025 
Vinarski-Peretz, H., \& Carmeli, A. (2011). Linking care felt to engagement in innovative behaviors in the workplace: The mediating role of psychological conditions. Psychology of Aesthetic, Creativity, and the Arts, 5, 43-53. http://doi.org/10.1037/a0018241

Zaitouni, M., \& Ouakouak, M.L. (2018). The impacts of leadership support and coworker support on employee creative behavior. International Journal of Productivity and Performance Management, 67(9), 1745-1763. http:// doi.org/10.1108/IJPPM-10-2017-0264

Zientara, P. (2017). Socioemotional wealth and corporate social responsibility: A critical analysis. Journal of Business Ethics, 144(1), 185-189. http://doi. org/10.1007/s10551-015-2848-1

Zhang, X., \& Zhou, J. (2014). Empowering leadership, uncertainty avoidance, trust, and employee creativity: Interaction effects and a mediating mechanism. Organizational Behavior and Human Decision Processes, 124, 150-164. http://doi.org/10.1016/j.obhdp.2014.02.002

Zhou, J., \& George J.M. (2003). Awakening employee creativity. The role of leader emotional intelligence. Leadership Quarterly, 14, 545-568. http:// doi.org/10.1016/S1048-9843(03)00051-1

\begin{abstract}
Abstrakt
Celem badania jest rozpoznanie, czy firmy rodzinne wdrażajqce kreatywne pomysły swoich pracowników sq bardziej innowacyjne niż pozostałe firmy rodzinne, tj. czy wdrażajq więcej innowacji produktowych, procesowych, marketingowych i organizacyjnych. W artykule eksploruje się zwiq̨zek między innowacjami wdrażanymi w firmach rodzinnych i zaangażowaniem tych firm w prowadzenie działań stymulujacych innowacyjne myślenie pracowników firmy przez budowanie klimatu zaufania w pracy, wspieranie rozwoju pracowników oraz wspieranie integracji zespołu. Realizacja postawionych celów została osiqgnięta w oparciu o analizę wyników badania pierwotnego przeprowadzonego w Polsce na próbie 353 firm rodzinnych. Analiza statystyczna wyników badania wykazała, że firmy rodzinne wdrażajq̨ce kreatywne rozwiqzania swoich pracowników, wprowadzajq istotnie więcej innowacji produktowych, niż inne firmy rodzinne. Nie ma jednak różnic między tymi dwiema grupami firm rodzinnych w zakresie wdrażania innowacji organizacyjnych, procesowych i marketingowych. Nasza analiza wykazała również, że: (i) wspieranie rozwoju pracowników jest niezależnym czynnikiem wpływajqcym na innowacje produktowe, procesowe i organizacyjne firm rodzinnych; oraz że (ii) budowanie integracji zespołu przez firmę jest niezależnym czynnikiem wpływajqcym na innowacje procesowe.
\end{abstract}

Słowa kluczowe: firmy rodzinne, innowacje, kreatywność, innowacje produktowe, innowacje procesowe, innowacje organizacyjne, innowacje marketingowe, Polska 


\section{Biographical notes}

Izabella Steinerowska-Streb holds a Ph.D. in economics from the University of Economics in Katowice where she currently works as Assistant Professor in the Department of Entrepreneurship and Management Innovation. Her research is focused on entrepreneurship, innovation, organizational creativity, small and medium firms' behavior, family businesses. She is the author and co-author of over 110 scientific outputs, including journal articles, student textbooks, and monographic books.

Grzegorz Głód holds a Ph.D. in Management from the University of Economics in Katowice where he currently works as Professor in the Department of Entrepreneurship and Management Innovation and acts as Vice-Dean for Education on the Faculty of Economics. He specializes in the research on the competitiveness of enterprises, public sector governance and management tools, including, in particular, the field of controlling. He has been delivering a number of consulting and training projects through a business consulting company. His research is focused on entrepreneurship, innovation, health care services. He is the author and co-author of over 130 scientific publications in the field of management.

\section{Conflicts of interest}

The authors declare no conflict of interest.

\section{Citation (APA Style)}

Steinerowska-Streb, I., \& Głód. G. (2020). Innovations in Polish family firms. Exploring employee creativity and management practices that stimulate innovative thinking Journal of Entrepreneurship, Management and Innovation, 16(2), 231-260. https://doi.org/10.7341/20201628 